\title{
Co-Expression of Candidate Genes Regulating Growth Performance and Carcass Traits of Barki Lambs in Egypt
}

Nasser Ghanem ( $\square$ nassergo@agr.cu.edu.eg )

Cairo University https://orcid.org/0000-0002-0480-0959

Mohamed Zayed

Desert Research Center

Ismail Mohamed

Desert Research Center

Mona Mohammady

Desert Research Center

Mohamed Farag Shehata

Desert Research Center

\section{Research Article}

Keywords: Barki lambs, growth rate, Carcass traits, gene expression.

Posted Date: August 4th, 2021

DOI: https://doi.org/10.21203/rs.3.rs-708345/v1

License: (c) (i) This work is licensed under a Creative Commons Attribution 4.0 International License. Read Full License 


\section{Abstract}

Sheep are considered one of the main sources of animal protein in Egypt while surviving harsh desert conditions. Therefore, the aim of present study was to link the gene expression profile of selected candidate genes with growth performance and carcass traits of Barki lambs. Thirty-eight Barki lambs were kept and fed individually after weaning till 12 months of age. Lambs were divided into 3 groups (fast, intermediate and slow growing) according to growth performance. Carcass traits were recorded directly after slaughtering. Three samples were taken from different body tissues (eye muscle, liver and fat tail) of each group, directly during slaughtering and stored at $-80^{\circ} \mathrm{C}$ until RNA isolation. Real-time PCR was used to profile selected candidate genes (RPL7, CTP1, FABP4, ADIPOQ and CAPN3) and GAPDH was used as a housekeeping gene. The results indicated that, the final body weight was significantly $(P \leq$ $0.05)$ greater in fast $(49.9 \mathrm{Kg})$ and intermediate $(40.7 \mathrm{Kg})$ compared to slow growing animals $(30.8 \mathrm{Kg})$. The hot carcass weight was heavier $(P \leq 0.05)$ in fast, intermediate $(24.57$ and $19.07 \mathrm{Kg})$ than low growing lambs $(15.10 \mathrm{Kg})$. The blood profiles of T3 and T4 hormones showed no significant different among fast $(1.1 \mathrm{ng} / \mathrm{ml}$ and $8.5 \mu \mathrm{g} / \mathrm{dl})$, intermediate $(0.6 \mathrm{ng} / \mathrm{ml}$ and $12.4 \mu \mathrm{g} / \mathrm{dl})$ and slow growing lambs $(1.0 \mathrm{ng} / \mathrm{ml}$ and $10.5 \mu \mathrm{g} / \mathrm{dl})$. In addition, the total protein level was not differ in fast $(5.94 \mathrm{~g} / \mathrm{dl})$, intermediate $(6.52 \mathrm{~g} / \mathrm{dl})$ and slow growing lambs $(6.9 \mathrm{~g} / \mathrm{dl})$. Genes involved in protein biosynthesis (RPL7), fatty acid oxidation (CPT1) and lipolysis (FABP4) were up regulated in fast and intermediate growing lambs in all studied tissues. While, gene-regulating lipogenesis (ADIPOQ) was expressed similarly in fat and liver tissues, but increased its expression in muscle of fast and intermediate growing lambs. Expression of CAPN3 was increased in fast and intermediate growing compared to slow growing lambs. In conclusion, the current study indicated a link between variation in gene expression profile in main body tissues with growth performance and carcass weight of Barki lambs, which induced by the genetic makeup however; this hypothesis required a large population for validation. In addition, the transcriptional profile of CPT1, FABP4 RPL7 and CAPN3 are linked with growth performance and carcass traits of Barki lambs, providing an evidence for the importance of co-expression of these genes in body main tissues involved in this process.

\section{Introduction}

Sheep are considered one of the main sources of animal protein. In addition, sheep have the ability to survive in the desert by grazing low quality forage (Elshazly \& Youngs, 2019). Barki sheep are important genetic resources that raised under a transhumant animal farming system in the North Western coastal desert of Egypt with a population of 470,000 heads (11\% of the total Egyptian sheep population) and known to be well-adaptive to the harsh desert conditions (El-Wakil et al., 2013). Generally, sheep individuals of the same breed are varied in growth performance and final body weight at time of slaughter. Thus, selecting sheep individuals having faster growth rate and heavier body weight are crucial for meat production industry. Therefore, it is useful to apply the breeding program for meat production that target to select lambs that have greater average daily gain than their counterparts do in the same herd (Parker et al., 1991; Moghaddam et al., 2021). 
Indeed, investigation of factors controlling sheep growth based on monitoring live body weights over a relevant time is of major interest among scientists and meat producers (Lupi et al., 2015; Moghaddam et al., 2021). Moreover, determining which factors influence the growth curve supports management and improvement program of sheep breeding. The growth performance of farm animals is an important economic trait that regulated by genetic and non-genetic factors (Alemneh \& Getabalew, 2019). In addition, the growth performance of sheep is influenced by age of the dam, pre-mating weight of the dam, type of birth, sex, breed and season of birth, which all considered as non-genetic factors (Yilmaz et al., 2007). Taken into consideration that other factors such as slaughtering animals at immature bodyweights, poor genetic potential of the local breeds and poor feeding conditions are major causes contributing of low meat production (Kefelegn et al., 2019). Therefore, it is required to get all information on growth rate and the maturity degree of live body weight relevant to carcass composition for genetic selection plan (Massender et al., 2019).

Understanding the genetic changes underlying phenotypic variation in domestic sheep (Ovis aries) may facilitate our efforts towards further improvement. Moreover, identification of genes underlying sheep growth performance would support worldwide efforts in increasing mutton production (Wang et al., 2015). In this regard, gene expression profile was applied to detect growth performance of three Egyptian sheep breeds (Ashour et al., 2020; Miao et al., 2015). However, there is no available data that linked expression profile and both growth and carcass traits of Egyptian sheep. Therefore, investigating the transcriptome profile of muscle tissues, especially with reference to transcription regulatory proteins, would provide useful information to improve the production and quality of sheep meat (Chao et al., 2016; Sun et al., 2016; Zhang et al., 2013). Actually, muscle growth and development are regulated by core genes and signal transduction pathways (Zhang et al., 2013; Zhang et al., 2015). Additionally, RPL7 was linked with pre-weaning gain in mutton merino (Zhang et al., 2013; Wang et al., 2015). Genes regulating fatty acid uptake and metabolism such as FABP4 are considered as potential candidate genes for meat tenderness (Xu et al., 2011). Therefore, the current research work aims to study the relationship of gene expression profile in major body tissues with growth performance, carcass traits and biochemical profile of Barki lambs.

\section{Materials And Methods}

\section{Experimental Animals}

The current study was conducted on Barki sheep flock, belongs to Maryout Research Station, $35 \mathrm{~km}$ south of Alexandria, Desert Research Center, Ministry of Agriculture and Land Reclamation, Egypt. Thirtyeight Barki lambs were kept and fed individually after weaning at 3 months of age (Initial body weight) till to 12 months of age (Final body weight). The lambs were kept in a cubical cement box of dimensions (120 width*150 length ${ }^{\star} 135$ height $\mathrm{cm}$ ), and has access to water and ration. Lambs were fed as per standard schedule (NRC, 1985) to cover their nutritional requirements. Lambs were fed a certain amounts of commercial concentrate mixture ( $12 \%$ crude protein) plus alfalfa hay (Trifolium alexandrinum). However, the amounts of concentrate feed mixture (CFM) offered to lambs were adjusted bi-weekly 
according to the live body weight changes. Moreover, water was available all the time for experimental animals.

\section{Experimental Design}

Lambs were weighed weekly after weaning and divided into 3 groups according to their growth rates (Fast, intermediate and slow growing). In addition, three samples of main body tissues (eye muscle, liver and fat tail) from three animlas representing each group were taken for gene expression profiling at the end of the fattening period (12 months of age). The genes selected in real-time PCR expression are regulators of different molecular pathways such as protein biosynthesis (RPL7), fat deposition or lipogenesis (ADIPOQ), fatty acid oxidation or lipolysis (CPT1 and FABP4) and muscle development (CAPN3).

\section{Slaughtering procedure and carcass trait}

Twenty-three lambs were slaughtered at 12 months of in meat processing unit at Maryout Research Station to evaluate carcass traits following the stranded protocol (Frild et al., 1963) lambs were fasted for approximately 24 hours before slaughtering. After slaughtering and bleeding, carcass were skinned and eviscerated before weighing. Weights of all non-carcass components (trachea, lungs, heart, liver, testes, spleen, kidneys, and kidney fat) were immediately weighed after removal from the body. The rumen and reticulum were cleaned and washed under cold running water, and then they were weighed. Empty body weights were recorded and all carcasses were held in a chiller at $4{ }^{\circ} \mathrm{C}$ for $24 \mathrm{~h}$ to evaluate cold carcass weight (Frild et al., 1963).

\section{Blood and tissue sampling}

Nine blood samples (3 from each group) were collected during slaughtering in tubes that contain EDTA as anticoagulant substance. Tissue samples (liver, tail fat, and muscle) were taken immediately from lambs after slaughter and kept in RNA later then kept at $-80^{\circ} \mathrm{C}$ till RNA extraction was performed in Cairo University Research Park, Faculty of Agriculture, Cairo University, Egypt.

\section{Analysis of blood T3 and T4 hormones profile}

Blood samples were collected in tubes containing EDTA as anticoagulant substance. Samples were centrifuged at $3000 \mathrm{rpm}$ for 20 minutes. Plasma was stored at $-20^{\circ} \mathrm{C}$ until estimation of T3 and T4 hormones using an enzyme immunoassay test kit (Chemux Bioscience Inc, USA, CA). The sensitivity value reported to be according to manufacturer information. The intra and inter-assay variation coefficients were 5.0 and $13.0 \%$, respectively.

\section{Measurement of blood total protein level}

The profile total protein $(\mathrm{g} / \mathrm{dl})$ was done using colorimetric methods according to instructions provided by the manufacturer company (Bio diagnostic, Giza, Egypt). The plasma samples $(0.025 \mathrm{ml})$ were mixed 
well with biuret reagent $(1.0 \mathrm{ml})$ and incubated at $37^{\circ} \mathrm{C}$ for $10 \mathrm{~min}$ the absorbance for standard and samples were measured using the spectrophotometer at $550 \mathrm{~nm}$ wavelengths.

\section{Measurement of blood glucose concentration}

The blood glucose profile $(\mathrm{mg} / \mathrm{dl})$ was measured using colorimetric methods according to instructions provided by the manufacturer company (Bio diagnostic, Giza, Egypt).

\section{Measurement of blood total lipids level}

The blood total lipids $(\mathrm{mg} / \mathrm{dl})$ was measured using colorimetric methods according to instructions provided by the manufacturer company (Bio diagnostic, Giza, Egypt).

\section{Measurement of blood calcium level}

The blood calcium level $(\mathrm{mg} / \mathrm{dl})$ was measured using colorimetric methods according to instructions provided by the manufacturer company (Bio diagnostic, Giza, Egypt).

\section{Gene expression Profile}

\section{Total RNA extraction}

The procedure of RNA isolation was performed using GeneJet RNA purification kit (Thermofisher Scientific, Vilnius, Lithuania) according to manufacture instructions. Approximately $20 \mathrm{mg}$ of tissue was weighed and grind with a pestle in a mortar using liquid nitrogen till powder was formed. The powder was transferred to a $1.5 \mathrm{ml}$ micro-centrifuge tube with $300 \mu \mathrm{l}$ of lysis buffer and $20 \mu \mathrm{l}$ of $\beta$-mercaptoethanol and vortexed for 20 seconds. A volume of $600 \mu$ l of diluted Proteinase K $(10 \mu l$ of included Proteinase K diluted in 590 $\mu$ l of Tris-EDTA (TE) buffer) was added and vortexed for 20 minutes then incubated for 10 minutes at room temperature and finally centrifuged for 10 minutes at $12000 \mathrm{xg}$. A volume of $450 \mu \mathrm{l}$ of ethanol was added and mixed by pipetting. $700 \mu$ l of lysate was transferred to the GeneJet RNA purification column and was inserted into a collection tube and then it was centrifuged for 1 minute at $12000 \mathrm{xg}$.

The flow through was discarded and placed the purification column in the tube. The previous step was repeated until all the lysate was transferred and centrifuged. The collection tube was discarded, which contained the flow though solution. The GeneJet RNA purification column was placed into a new $2 \mathrm{ml}$ collection tube. A volume of $700 \mu \mathrm{l}$ of wash buffer 1 was added to the GeneJet RNA purification column and centrifuged for 1 minute at $12000 \mathrm{xg}$. The flow through was discarded and the purification column was placed back into the collection tube, then $250 \mu \mathrm{l}$ of wash buffer 2 was added to the GeneJet RNA purification column and centrifuged at $12000 \mathrm{xg}$ for 2 minutes.

The collection tube containing the flow through solution was discarded and the GeneJet RNA purification column was transferred to a sterile $1.5 \mathrm{ml}$ RNase free micro-centrifuge tube. Nuclease free water (100 $\mu \mathrm{l})$ was added to the GeneJet RNA purification columns and centrifuged at $12000 \mathrm{xg}$ for 1 minute. The 
purification column was discarded. For DNA digestion, $1 \mathrm{ml}$ of DNAse (Thermo Scientific, California, USA) was added to $9 \mu \mathrm{l}$ of RNA sample and the mixture $(10 \mu \mathrm{l})$ was incubated in a thermal cycler for 30 minutes at $37^{\circ} \mathrm{C}$. After that, $1 \mathrm{ml}$ of EDTA was added to the mixture. The mixture (RNA, DNAse, and EDTA) was incubated in a thermal cycler (Thermofisher Scientific, CA, USA) for 10 minutes at $65^{\circ} \mathrm{C}$. Finally, the purity and concentration of extracted RNA were measured at A260/280 nm ratio (1.9-2.1) using NanoDrop $2000 \mathrm{C}$ (Thermofisher Scientific, Wilmington, DE, USA). The samples were stored at $-80^{\circ} \mathrm{C}$ freezer until cDNA synthesis.

\section{cDNA synthesis}

After adjusting the RNA concentration of all isolated RNA samples, synthesis of CDNA was done using revertAid First Strand cDNA Synthesis Kit (Thermofisher, USA). The reaction mix consisted of $1 \mu$ l of oligo (dT) 18 primer to $11 \mu \mathrm{l}$ of the adjusted RNA, $4 \mu$ of $5 x$ reaction buffer, and $2 \mu \mathrm{l}$ of $10 \mathrm{mM}$ dNTP for each RNA sample. Finally, $1 \mu$ of RiboLock RNase inhibitor and $1 \mu$ l of revertaid reverse transcriptase was added to reach a final volume of $20 \mu \mathrm{l}$ and samples were incubated in a thermal cycler (Thermofisher Scientific, CA, USA) for 60 minutes at $42^{\circ} \mathrm{C}$ followed by $70^{\circ} \mathrm{C}$ for 5 minutes. The cDNA samples were stored in $-20^{\circ} \mathrm{C}$ freezer till used for real-time PCR runs.

\section{Quantitative Real-time PCR}

A pair of primers (forward and reverse) was designed for each specific gene (GAPDH, ADIPOQ, CPT1, FABP4, RPL7and CAPN3) using Primer3 software (http://primer3.wi.mit.edu//) as shown in Table 1. The design of primers was based on gene sequences described in the GenBank database (www.ncbi.nlm.nih.gov). Real-time PCR was performed using glyceraldehyde 3-phosphate dehydrogenase (GAPDH) as housekeeping gene The real-time PCR was done in the 96 well plate (Thermofisher Scientific, Wilmington, DE, USA). The real-time PCR reaction mix is composed of $2 \mu \mathrm{l}$ of cDNA sample, $12 \mu \mathrm{l}$ of Maxima SYBR Green/ROX qPCR Master Mix (Thermofisher Scientific, CA, USA), $0.2 \mu l$ of specific reverse primer, $0.2 \mu \mathrm{l}$ of specific forward primer and $7.6 \mu \mathrm{l}$ of nuclease free water. Reaction was incubated in StepOnePlus ${ }^{\text {TM }}$ Real-Time PCR (Applied Biosystems, CA, USA). The reaction mix was incubated at $50^{\circ} \mathrm{C}$ for 2 minutes; initial denaturation was done for 10 minutes at $95^{\circ} \mathrm{C}$ and 40 cycles at $95^{\circ} \mathrm{C}$ (Denaturation) for 15 minute and final step at $60^{\circ} \mathrm{C}$ for 1 minute (annealing), at $95^{\circ} \mathrm{C}$ for 15 seconds and then $60^{\circ} \mathrm{C}$ for 1 minute. The results were expressed as $\mathrm{Ct}$ values and relative gene expression profile was estimated delta delta $C t$ analysis (2- $\Delta \Delta C T$ method) as done in our recent study (Ghanem et al., 2021).

\section{Statistical analysis}

The growth performance data and gene expression profile of the three different lambs of each experimental group (Fast, intermediate and slow growing animals) were analyzed using the procedure of General Linear Model (SAS, 2011). The statistical analysis was performed to test the effect of animal growth rate, carcass traits and biochemical measurements on gene expression profile of selected candidate transcripts by applying the following formula: 
$Y i j=\mu+G i+e i j$.

$\mathrm{Y}$ ijk= individual observation; $\mu=$ Overall mean; $\mathrm{Gi}=$ Effect of growth rate; eij = Experimental error; $\mathrm{i}=1,2,3$ (fast, intermediate and slow).

The mean values were compared for statistical significance using Duncan's range test (1955).

Differences were considered statistically significant at $P \leq 0.05$.

\section{Results}

\section{Growth performance traits}

The birth weight of fast $(4.10 \mathrm{Kg})$ growing animals was similar of that of slow growing lambs $(2.82 \mathrm{Kg})$ however; both groups had heavier weight at birth than intermediated growing animals $(3.83 \mathrm{Kg})$. The least square means estimates of initial body weight, the final body weight, average daily gain and total body gain are shown in Table 2 . The initial body weight was significantly different $(P \leq 0.05)$ in fast $(27.7$ $\mathrm{Kg})$, intermediate $(22.5 \mathrm{Kg})$ and slow growing lambs $(15.8 \mathrm{Kg})$. Accordingly, the final body weight was greater $(P \leq 0.05)$ in fast $(49.9 \mathrm{Kg})$ and intermediate $(40.7 \mathrm{Kg})$ than slow growing animals $(30.8 \mathrm{Kg})$ as shown in Table 2. The average daily gain was increased $(P \leq 0.05)$ in fast $(173.6 \mathrm{gm})$ and intermediate $(112.0 \mathrm{gm})$ compared to slow growing animals $(92.3 \mathrm{gm})$. Additionally, the total body gain was significant $(P \leq 0.05)$ greater in fast $(22.3 \mathrm{Kg})$ and intermediate $(18.2 \mathrm{Kg})$ and slow growing animals $(15.0 \mathrm{Kg})$.

\section{Carcass traits}

The hot carcass weight (Table 3 ) was increased $(P \leq 0.05)$ in fast and intermediate compared to slow growing lambs which recorded 24.57, 19.07 and $15.10 \mathrm{Kg}$, respectively. Moreover, a liver weight of slaughtered lambs (Table 3 ) was significantly increased $(P \leq 0.05)$ in fast $(0.62 \mathrm{Kg})$ compared to intermediate $(0.50 \mathrm{Kg})$ and slow growing lambs $(0.54 \mathrm{Kg})$. On the other hand, dressing percentage, noncarcass fat and tail fat were not significantly different among fast $(48.83 \mathrm{Kg}, 1.46 \mathrm{Kg}$ and $1.65 \mathrm{Kg})$, intermediate $(47.48 \mathrm{Kg}, 1.21 \mathrm{Kg}$ and $1.79 \mathrm{Kg})$ and slow growing lambs $(46.90 \mathrm{Kg}, 1.18 \mathrm{Kg}$ and $1.48 \mathrm{Kg})$. Furthermore, total body fat (non-carcass fat + tail fat $\mathrm{Kg}$ ) was increased but not significantly in in fast $(2.67 \mathrm{Kg})$ and intermediate $(2.61 \mathrm{Kg})$ compared to slow growing lambs $(2.23 \mathrm{Kg})$.

\section{The blood profile of T3 and T4 hormone}

The blood profile of thyroid hormones (T3 and T4) were not significantly $(P \leq 0.05)$ different among fast $(1.1 \mathrm{ng} / \mathrm{ml}$ and $8.1 \mu \mathrm{g} / \mathrm{dl})$, intermediate $(0.6 \mathrm{ng} / \mathrm{ml}$ and $12.4 \mu \mathrm{g} / \mathrm{dl})$ and slow $(1.0 \mathrm{ng} / \mathrm{ml}$ and $10.5 \mu \mathrm{g} / \mathrm{dl})$ growing lambs (Table 4).

\section{The blood profile of total protein}


The total protein profile was not significantly different in fast $(6.53 \mathrm{~g} / \mathrm{dl})$, intermediate $(5.97 \mathrm{~g} / \mathrm{dl})$ and slow $(6.07 \mathrm{~g} / \mathrm{dl})$ growing lambs (Table 4$)$.

\section{The blood profile of total lipids}

The level of total lipids was not significantly different in fast $(378.0 \mathrm{mg} / \mathrm{dl})$, intermediate $(358.0 \mathrm{mg} / \mathrm{dl})$ and slow (392 mg/dl) growing lambs (Table 4).

\section{The blood profile of glucose level}

The profile of blood glucose was not significantly different in fast $(74.87 \mathrm{mg} / \mathrm{dl})$, intermediate $(75.73$ $\mathrm{mg} / \mathrm{dl})$ and slow (74.17 mg/dl) growing lambs (Table 4).

\section{The blood profile of calcium profile}

The concentration of blood calcium was not significantly different in fast $(10.13 \mathrm{mg} / \mathrm{dl})$, intermediate $(10.0 \mathrm{mg} / \mathrm{dl})$ and slow $(10.87 \mathrm{mg} / \mathrm{dl})$ growing lambs (Table 4).

\section{Gene expression profile of selected candidate transcripts}

The expression profile of protein biosynthesis regulating candidate gene (RPL7) was significantly different $(\mathrm{P} \leq 0.05)$ in muscle (Longissmus dorsi) and liver tissues of fast, intermediate and slow growing lambs. While, adipose tissue of intermediate growing had a higher RPL7 expression profile than in fast and slow growing lambs (Figure 2).

The transcript abundance of CPT1 involved in $\beta$-oxidation process was increased significantly in muscle, liver samples of fast growing lambs than intermediate growing. In addition, the intermediate growing lambs had greater transcript abundance than slow growing (Figure 3). However, the expression of this gene in fat tissue had similar greater abundance $(P \leq 0.05)$ in fast and intermediate than slow growing lambs.

Transcript abundance of FABP4 (Lipogenesis) was increased in all body tissues in fast and intermediate compared with slow growing lambs (Figure 4).

The expression of ADIPOQ was increased $(P \leq 0.05)$ in muscle, liver and fat tissues of fast and intermediate compared to slow growing lambs (Figure 5). In addition, the adiponectin expression level of muscle collected from fast growing lambs was higher than intermediate growing lambs.

The transcript abundance of CAPN3 was greater significantly in muscle of fast and intermediate than slow growing animals (Figure 6).

\section{Discussion}


The availability of sheep feed is not stable in terms of both quantity and quality particularly in the subtropical region. Therefore, it is a privilege to select animals that recorded fast grow rate for meat production (Parker et al., 1991). In lamb production system, the growth rate prior to weaning is considered a vital factor in the determination of system performance, as fast growing lambs, that quickly reaches slaughter weight, will proportionately reduce the maintenance cost. In the current study, initial body weight of fast growing lambs was greater than those intermediate and slow growing lambs, which were positively linked with increased final body weight in fast growing lambs. The total and average daily body gain were increased $(P \leq 0.05)$ in fast growing lambs $(22.3 \mathrm{Kg}$ and $173.6 \mathrm{gm})$ compared to intermediate $(18.2 \mathrm{Kg}$ and $112.0 \mathrm{gm})$ and slow growing lambs $(15.0 \mathrm{Kg}$ and $92.3 \mathrm{gm})$.

The growth rate of Awassi lambs were increased than Washera and Wollo highland breeds reflecting the body weight gain genetic potentiality among these three breeds (Moghaddam et al., 2021). The increased body gain was the reflected in heavier final body weight of fast growing animals $(49.9 \mathrm{Kg})$ compared to intermediate $(40.7 \mathrm{Kg})$ and slow growing groups $(30.8 \mathrm{Kg})$. The average body weight of Egyptian breeds is approximately $51 \mathrm{~kg}$ in Ossimi, $53 \mathrm{~kg}$ in Rahmani and $44 \mathrm{~kg}$ in Barki at marketing age (Almahdy et al. 2000); Ashour et al., 2020; El-Malky et al. 2019; Hassan 2017; Khalifa et al. 2013; Marai et al. 2009; Miao et al., 2015).

The biogenesis of ribosome and translation of protein are essential for the cells' growth, differentiation, proliferation and the animal development (Zhou et al., 2015). The building of muscle fibers and synthesis of protein required for animal growth is regulated partially by ribosomal gene activity when proper nutrition is provided (Nader 2014). Indeed, the synthesis rate of muscle protein is mainly dependent on the content of ribosomes in muscle fibers (Millward et al., 1973). The expression profile of protein biosynthesis candidate gene (RPL7) was greater significantly in muscle (Longissmus dorsi) and liver tissues of fast and intermediate growing lambs than in slow growing lambs which is in line with increased body mass of fast and intermediate growing lambs. Indeed, ribosomal proteins have a direct regulatory effect on the synthesis of protein in different animal species (Costa et al., 2004; Han \& Hickey 2005; Wang et al, 2012).

Moreover, it was found that the RPL7 was down-regulated in the broilers liver during feed restriction while in the adipose tissue there was no detection of differential expression (Wang et al, 2012). It was also reported that the genes involved in protein are altered severely due to diet restriction in porcine skeletal muscle (Costa et al., 2004; Han \& Hickey, 2005). Sheep genome-wide study proposed RPL7 as candidate gene associated with growth performance and meat production traits (Zhang et al., 2013). Additionally, RPL7 was linked with pre-weaning gain in German mutton merino (Wang et al., 2015). Noteworthy, our data indicated higher expression profile of this gene in muscle and liver tissues compared to adipose tissue. While, Thorrez et al., (2008) have demonstrated increased expression of RPL3 in adipose and muscle tissues compared to liver of human cells. This spatiotemporal variation between species and tissues reflect changing of the content and activity of ribosome protein biosynthesis during different phases of body growth. In support of this idea, Cassar-Malek et al., (2007) indicated a change in the 
expression of ribosomal protein genes during different time points of bovine semitendinosus muscle development in prenatal fetus stage.

The increasing in body mass of fast and intermediate than the slow growing lambs was resulting from a higher expression of Calpain3 (CAPN3) gene. This result may be linked with the ability of each group growth rate. Calpains (CAPN) encodes cysteine-activated intracellular proteases associated with an increased number of myoblasts by controlling mitotic cycle (Barnoy et al., 1997; Cottin et al., 1994). Indeed, sheep had TT genotype of CAPN had heavier birth weight, final body weight and average daily gain those with other genotype, while CC genotype recorded the lowest values of these traits (Mahrous et al., 2016).

In support to the potential role of CAPN3 in enhancing sheep body weight, several studies have demonstrated its genetic association with sheep growth performance and meat production traits (Koohmaraie et al., 1992; Nassiry et al., 2007; Naveen et al., 2015). Therefore, it could be revealed that ribosomal and calpain encoded genes are co-expressed to enhance sheep body mass by enhancing myoblast proliferating activity and protein accumulation independent of the hormonal profile of thyroid hormones. Although, increased plasma T4 concentration was recorded in Suffolk ewes compared to Gulf Coast native ewes, which was positively linked with larger body size and improved growth performance (Williams et al., 2004).

The increased body growth required high-energy demand. In this regard, fatty acids are metabolized by oxidation pathway in mitochondria to give acetyl-CoA, which is completely broken down via the Krebs cycle, or converted into acetate as an energy source (Guzman et al., 1993). Indeed, approximately 4-30 \% of circulating acetate and $10-55 \%$ of beta-hydroxybutyrate may be derived from hepatic oxidation of long chain fatty acids in cattle (Mery et al., 1992). The catabolism of fatty acid occurred in the mitochondria by $\beta$-oxidation pathway (Sun et al., 2020). Our results demonstrated that the transcript abundance of CPT1 involved in $\beta$-oxidation process was shown to be higher in muscle, liver samples of fast growing lambs than intermediate and slow growing lambs; additionally the intermediate growing lambs had greater transcript abundance than slow growing lambs. While, fast and intermediate growing lambs had similar expression of this gene in fat tissue, but both had higher expression than slow growing lambs.

A study that has been done in the fetal rabbit shown that cultured hepatocytes with long chain fatty acids increased CPT I expression (Prip-Buus et al., 1995). The up-regulation of this gene in fast growing lambs may be due to increased metabolic demand to meet accelerated growth performance in fast and intermediate growing lambs which dependent on the utilization of fatty acids in both liver and developing muscle fibers. In support of this idea, Price et al., (2003) reported a 10-fold increase in the expression of mRNA encoding CPT1B in lactating ewes compared to late pregnancy and control mammary gland cells. In addition, down regulation of CPT1b reduced fatty acid metabolism and subsequently resulted in obesity of rats (Warfel et al., 2017). 
Bionaz et al., (2012) indicated that Madin-Darby bovine kidney cells (MDBK) increased long chain fatty acid oxidation through greater enhanced transport of FABP4 gene into cytoplasm in addition to CPT1A in the mitochondria, which was revealed by up regulation of these genes that leading to the synthesis of TAG and cholesterol are under the control of PPAR-a. Transcript abundance of FABP4 was increased in all examined body tissues in fast and intermediate growing compared with slow growing lambs. A genetic SNP inFABP4 gene was associated with meat tenderness in sheep (Xu et al., 2011). The data of study strongly support the idea that oxidation of long chain fatty acid oxidation is a key determining molecular mechanism explaining the variation of sheep growth performance. Additionally, the transcript abundance of ADIPOQ was higher in muscle, liver and fat tissues of fast and intermediate growing than slow growing lambs. Moreover, the adiponectin expression level of muscle collected from fast growing was higher than intermediated growing lambs.

Adipokines have an important biological role in regulating lipid metabolism (Reynolds and Vickers, 2019). The transcript abundance of ADIPOQ was higher in muscle, liver and fat tissues of fast and intermediate growing than those of slow growing lambs. In addition, the adiponectin expression level of muscle collected from fast growing was higher than intermediated growing lambs. They found that fat ADIPOQ mRNA expression (1 week after calving) had a positive correlation with free fatty acid so, the mobilization of body reserves (Elis et al., 2013). Another study was done on New Zealand Romney lambs, where they reported an association between the growth and carcass traits and the ADIPOQ haplotypes (An et al., 2017). This supports that the fast-growing sheep and the intermediate growing sheep both had a higher growth as they had higher levels of expression of the ADIPOQ gene. Moreover, a genomic variant (SNP) ADIPOQ were associated with marbling score of Hanwoo cattle (Shin et al., 2013; Choi et al., 2015). Therefore, this study suggested that ADIPOQ gene in addition to its role in regulating deposition and differentiation of fat in the cattle it could be used to differentiate sheep with varied grow and carcass traits.

\section{Conclusions}

The data of the current investigation indicated a link between variation in gene expression profile in main body tissues and growth performance in addition carcass traits of Barki lambs in Egypt. Which could be induced by the genetic makeup independent of the levels of thyroid hormones, however, this hypothesis required a large population for validation. In addition, the transcriptional profile of CPT1, FABP4, RPL7 and CAPN3 are linked with growth performance also carcass traits of lambs, providing an evidence for the importance of co-expression of these genes in different body tissues involved in this process.

\section{Declarations}

\section{Funding}

The current study was partially supported financially by Desert Research Center, Cairo, Egypt. 


\section{Conflicts of interest}

All authors of the present study declared no any competing interests that could prejudices this work.

\section{Availability of data and material}

The data and materials of this study will be available on request.

\section{Code availability}

Not applicable.

\section{Authors' contributions}

All authors of the present study have contributed equally by suggesting and designing the experiment in addition to writing and revising of the manuscript.

\section{Ethics approval}

The Institutional Animal Care and Use Committee of Desert Research Center has accepted to conduct and approved this study.

\section{Consent to participate}

The authors of this work has agreed to participate in present study.

\section{Consent for publication}

The authors of this study has accepted to submit the current manuscript to Tropical Animal Health and Production.

\section{References}

1. Alemneh, T.; Getabalew, M. 2019. Factors Influencing the Growth and Development of Meat Animals. International Journal of Animal Science, 3: 1-5.

2. Almahdy, H.; Tess, M.W.; El-Tawil, E.; Shehata, E.; Mansour, H. 2000. Evaluation of Egyptian sheep production systems: II. Breeding objectives for purebred and composite breeds. Journal of Animal Science, 78: 288-295.

3. An, Q.; Zhou, H.; Hu, J.; Luo, Y.; Hickford, J.G.H. 2017. Haplotypes of the Ovine Adiponectin Gene and Their Association with Growth and Carcass Traits in New Zealand Romney Lambs. Genes (Basel), 8: 160.

4. Barnoy, S.; Glaser, T.; Kosower, N.S. 1997. Calpain and calpastatin in myoblast differentiation and fusion effects of inhibitors. Biochim Biophys Acta, 1358: 181-188. 
5. Bionaz, M.; Thering, B.J.; Loor, J.J. 2012. Fine metabolic regulation in ruminants via nutrient-gene interactions: saturated long-chain fatty acids increase expression of genes involved in lipid metabolism and immune response partly through PPAR-a activation. British Journal of Nutrition, 107: 179-91.

6. Cassar-Malek, I.; Passelaigue, F.; Bernard, C.; Leger, J.; Hocquette, J.F. 2007. Target genes of myostatin loss-of-function in muscles of late bovine fetuses. BMC Genomics, 8:63.

7. Chao, T.; Wang, G.; Wang, J.; Liu, Z.; Ji, Z.; Hou, L.; Zhang, C. 2016. Identification and classification of new transcripts in dorper and small-tailed han sheep skeletal muscle transcriptomes. PLoS One, 11:e0159638.

8. Choi, Y.; Davis, M.E.; Chung, H. 2015. Effects of genetic variants in the promoter region of the bovine adiponectin (ADIPOQ) gene on marbling of Hanwoo beef cattle. Meat Science, 105: 57-62.

9. Costa, N.D.; Mcgillivray, C.; Bai, Q.; Wood, J.D.; Evans, G.; Chang, K.C. 2004. Restriction of dietary energy and protein induces molecular changes in young porcine skeletal muscles. The journal of Nutrition, 134: 2191-2199.

10. Cottin, P.; Brutis, J.J.; Poussard, S.; Elamrani, N.; Broncard, S.; Ducastaing, A. 1994. Ca2_-dependent proteinases (calpains) and muscle cell differentiation. Biochim Biophys Acta, 1223: 170-178.

11. Elis, S.; Coyral-Castel, S.; Freret, S.; Cognié, J.; Desmarchais, A.; Fatet, A.; Rame, C.; Briant, E.; Maillard, V.; Dupont, J. 2013. Expression of adipokine and lipid metabolism genes in adipose tissue of dairy cows differing in a female fertility quantitative trait locus. Journal of Dairy Science; 9: 7591-602.

12. El-Malky, O.M.; Mostafa, T.H.; Ibrahim, N.H.; Younis, F.E.; Abd El-Salaam, A.M.; Tag El-Din, H.A. 2019. Comparison between productive and reproductive performance of Barki and Ossimi ewes under Egyptian conditions. Egyptian Journal of Sheep \& Goat Sciences, 14: 61-82.

13. Elshazly, A.G.; Youngs C.R. 2019. Feasibility of utilizing advanced reproductive technologies for sheep breeding in Egypt. Part 1. Genetic and nutritional resources. Egyptian Journal of Sheep and goat Sciences, 14: 39-52.

14. El-Wakil, S.; Manal Elsayed. 2013. Genetic, phenotypic and environmental trends towards improving body weight in Barki sheep Egyptian Journal of Sheep and goat Sciences, 8: 1-510.

15. Frild, R.A.; Kemp, J.D.; and Varney, W.Y. 1961. Indices for lamb carcass composition. Journal of Animal Science, 322: 218.

16. Ghanem, N.; Ahmed, D.A.R.; Dessouki, S.M.; Faheem, M.S.; Gad, A.Y.; Peippo, J.; Barkawi, A.H. 2021. Cellular and molecular alterations of buffalo oocytes cultured under two different levels of oxygen tension during in vitro maturation. Zygote, , 24:1-11.

17. Guzman, M.; Geelen, M.J.H. 1993. Regulation of fatty acid oxidation in mammalian liver. Biochim. Biophys. Acta, 1167: 227-241.

18. Han, E.S.; Hickey, M. 2005. Microarray Evaluation of Dietary Restriction. The Journal of Nutrition, 135: $1343-1346$.

19. Hassan, T.M.M. 2017. Effects of weaning age and some other factors on growth performance of Ossimi lambs. Egyptian Journal of Sheep \& Goat Sciences, 12: 29:38. 
20. Kefelegn, K.; Mekonnen, T.; Girma, A.; Goetsch AL. 2019. Analysis of Growth Performance Data in Sheep using Linear Mixed Model. World Jouenal of Agriculture and Soil Sciences, 2 :1-5.

21. Khalifa, A.I.; Ahmed, M.E.; Hafez, Y.H.; El-Zolaky, O.A.; Bahera, K.M.; Abido, A.A. 2013. Age at puberty and fertility of Rahmani sheep fed on biological inoculated corn silage. Annals of Agricultural Science, 58: 163-172.

22. Koohmaraie M. 1992. Ovine skeletal muscle multi-catalytic proteinase complex (proteasome): purification, characterization, and comparison of its effects on myofibrils with mu-calpains. Journal of Animal Science, 70: 3697-3708.

23. Lupi, T.M.; Nogales, S.; León, J.M.; Barba, C.; Delgado, J.V. 2015. Characterization of commercial and biological growth curves in the Segureña sheep breed. Animal, 9: 1341-1348.

24. Mahrous, K.F.; Hassanane, M.S.; Shafey, H.I.; Abdel Mordy, M.; Rushdi, H.E. 2016. Association between single nucleotide polymorphism in ovine Calpain gene and growth performance in three Egyptian sheep breeds. Journal of Genetic Engineering Biotechnology, 14: 233-240.

25. Marai, I.F.M.; Daader, A.H.; Bahgat, L.B. 2009. Performance traits of purebred Ossimi and Rahmani lambs and their crosses with Finnsheep born under two accelerated mating systems. Archives Animal Breeding, 52: 497-511.

26. Massender, E.; Brito, L.F.; Cánovas, A.; Baes, C.F.; Kennedy, D.; Schenkel, F.S. A. 2019. Genetic evaluation of growth, ultrasound, and carcass traits at alternative slaughter endpoints in crossbred heavy lambs. Journal of Animal Science, $97: 521-535$.

27. Mery, R.S.; Liesman, J.S.; Herdt, T.H. 1992. Metabolism of long-chain fatty acids by ruminant liver. Journal of Nutrion, 122: 832-837.

28. Miao, X.; Luo, Q.; Qin, X. 2015. Genome-wide analysis reveals the differential regulations of mRNAs and miRNAs in Dorset and Small Tail Han sheep muscles. Gene, 562, 188-196.

29. Millward, D.J.; Garlick, P.J.; James, W.P.; Nnanyelugo, D.O.; Ryatt, J.S. 1973. Relationship between protein synthesis and RNA content in skeletal muscle. Nature, 241: 204-205.

30. Moghaddam, V.K.; Elahi, M.Y.; Nasri, M.H.F.; Elghandour, M.M.M.Y.; Monroy, J.C.; Salem, A.Z.M.; Karami, M.; Mlambo, V. 2021. Growth performance and carcass characteristics of finishing male lambs fed barberry pomace-containing diets. Animal Biotechnology, 32:178-184.

31. Nader, G.A.J. 2014. Ribosomes 'muscle up' postnatal muscle growth. Journal of Physiology, 592: 5143.

32. Nassiry, M.R.; Shahroudi, F.E.; Tahmoorespur, M.; Javadmanesh, A. 2007. Genetic variability and population structure in beta-lactoglobulin, calpastatin and calpain loci in Iranian Kurdi sheep. Pak. J. Biol. Sci, 10: 1062-1067.

33. Naveen, K.S.; Jayashankar, M.R.; Nagaraja, R.; Nagaraja, C.S.; Nadeem, F.; Satyanarayana, K. 2015. Genetic polymorphism of ovine Calpine gene in Bander sheep. International Journal of Scienticic Environmental Technology; 4: 804-812.

34. NRC. 1985. Nutrient requirements of sheep. 6th Edition, National Academy of Sciences, National Research Council, Washington, D.C. 
35. Parker, W.J.; McCutcheon, S.N.; Wickham, G.A. 1991. Effect of administration and ruminal presence of chromic oxide controlled release capsules on herbage intake of sheep. New Zealand Journal of Agricultural Research (NZJAR), 34:193-200.

36. Price, N.T.; Jackson, V.N.; van der Leij, F.R.; Cameron, J.M.; Travers, M.T.; Bartelds, B.; Huijkman, N.C.; Zammit, V.A. 2003. Cloning and expression of the liver and muscle isoforms of ovine carnitine palmitoyltransferase 1: residues within the $\mathrm{N}$-terminus of the muscle isoform influence the kinetic properties of the enzyme. Biochem Journal, 372: 871-879.

37. Prip-Buus, C.; Thumelin, S.; Chatelain, F.; Pegorier, J.P.; Girard, J. 1995. Hormonal and nutritional control of liver fatty acid oxidation and ketogenesis during development. Biochem. Soc. Trans, 23: 500-506.

38. Reynolds, C.M.; Vickers, M.H. 2019. The role of adipokines in developmental programming: evidence from animal models. Journal of Endocrinology, 242: T81-T94.

39. SAS: Statistical analysis system institute. 20011. SAS institute, Inc., Cary, MC, USA.

40. Shin, S; Chung, E. 2013. Novel SNPs in the bovine ADIPOQ and PPARGC1A genes are associated with carcass traits in Hanwoo (Korean cattle). Molecular Biology Report, 40: 4651-60.

41. Sun, H.Z.; Zhou, M.; Wang, O.; Chen, Y.; Liu, J.X.; Guan, L.L. 2020. Multi-omics reveals functional genomic and metabolic mechanisms of milk production and quality in dairy cows. Bioinformatics, 36: $2530-2537$.

42. Sun, L.; Bai, M.; Xiang, L.; Zhang, G.; Ma, W.; Jiang, H. 2016. Comparative transcriptome profiling of longissimus muscle tissues from Qianhua Mutton Merino and Small Tail Han sheep. Scientific Report, 6:33586.

43. Thorrez, L J.; Van Deun, K J.; Tranchevent, L.C J.; Van Lommel, L J.; Engelen, K J.; Marchal, K J.; Moreau, Y J.; Van Mechelen, I J.; Schuit, F. 2008. Using Ribosomal Protein Genes as Reference: A Tale of Caution. PLoS One, 3: e1854.

44. Wang, H.; Zhang, L.; Cao, J.; Wu, M.; Ma, X.; Liu, Z.; Liu, R.; Zhao, F.; Wei, C.; Du, L. 2015. Genome-Wide Specific Selection in Three Domestic sheep breeds. PLoS One, 10: e0128688.

45. Ashour, G.; Gad, A.; Fayed, A.K., Ashmawy, N.A.; El- Sayed, A. 2020. Evaluation of growth performance, blood metabolites and gene expression analysis in Egyptian sheep breeds, in relation to age. World Veterinary Journal, 10: 18-29.

46. Wang, J.; Chen, W.; Kang, X.; Huang, Y.; Tian, Y.; Wang, Y. 2012. Identification of differentially expressed genes induced by energy restriction using annealing control primer system from the liver and adipose tissue of broilers. Poultry Science, 91: 972-978.

47. Warfel, J.D.; Vandanmagsar, B.; Dubuisson, O.S.; Hodgeson, S.M.; Elks, C.M.; Ravussin, E.; Mynatt ,R.L. 2017. Examination of carnitine palmitoyltransferase 1 abundance in white adipose tissue: implications in obesity research. Am J Physiol Regul Integr Comp Physiol., 312: R816-R820.

48. Williams, C.C.; Calmes, K.J.; Fernandez, J.M.; Stanley, C.C.; Lovejoy, J.C.; Bateman, H.G.; Gentry, L.R.; Gantt, D.T.; Harding, G.D. 2004. Glucose metabolism and insulin sensitivity in Gulf Coast native and Suffolk ewes during late gestation and early lactation. Small Ruminant Research, 54: 167-171. 
49. Xu, Q.L.; Tang G.W.; Zhang Q.L.; Huang Y.; KLiu., Y.X.; Quan K.; Zhu K.Y.; Zhang C.X. 2011. The FABP4 gene polymorphism is associated with meat tenderness in three Chinese native sheep breeds. Czech J. Anim. Sci., 56: 1-6.

50. Yilmaz, O.; Denk, H.; Bayram, D. 2007. Effects of lambing season, sex and birth type on growth performance in Norduz lambs. Small Ruminant Research, 68: 336-339.

51. Zhang, C.; Wang, G.; Hou, L.; Ji, Z.; Wang, J. 2015. De novo assembly and characterization of the skeletal muscle transcriptome of sheep using Illumina paired-end sequencing. Biotechnology Letters , 37: 1747-56.

52. Zhang, C.; Wang, G.; Wang, J.; Ji, Z.; Liu, Z.; Pi, X.; Chen, C. 2013. Characterization and comparative analyses of muscle transcriptomes in Dorper and small-tailed Han sheep using RNA-Seq technique. PLoS One, 8:e72686.

53. Zhang, L.; Liu, J.; Zhao, F.; Ren, H.; Xu, L.; Lu, J.; Zhang, S.; Zhang, X.; Wei, C.; Lu, G.; Zheng, Y.; Du, L. 2013. Genome-wide association studies for growth and meat production traits in sheep. PLoS One, 8:e66569.

54. Zhou, X.; Liao, W.J.; Liao, J.M.; Liao, P.; Lu,H. 2015. Ribosomal proteins: functions beyond the ribosome. Journal of Molecular Cell Biology, 7: 92-104.

\section{Tables}


Table 1

Primer sequences of genes used for quantitative real-time PCR.

\begin{tabular}{|c|c|c|c|}
\hline $\begin{array}{l}\text { Gene } \\
\text { Name }\end{array}$ & $\begin{array}{l}\text { Gene bank accession } \\
\text { number }\end{array}$ & Primer sequence & $\begin{array}{l}\text { Fragment size } \\
\text { (bp) }\end{array}$ \\
\hline \multirow[t]{2}{*}{ CPT1 } & NM_001009259.1 & $\begin{array}{l}\text { F: 5'- TCACCACTACGACCCAGAGG- } \\
3^{\prime}\end{array}$ & 95 \\
\hline & & $\begin{array}{l}\text { R: 5'- AGGACTTGTCGAACCACCTG- } \\
3^{\prime}\end{array}$ & \\
\hline \multirow[t]{2}{*}{ ADIPOQ } & KM216385.1 & F: 5'- TTCCCATTCGCTTTACCAAG-3' & 122 \\
\hline & & $\begin{array}{l}\mathrm{R}: 5^{\prime}-\mathrm{CAAGTAGACGGTAATGTGGT-} \\
3^{\prime}\end{array}$ & \\
\hline \multirow[t]{2}{*}{ FABP4 } & NM_001114667.1 & $\begin{array}{l}\text { F: 5'- GCCAGGAATTTGATGAAGTC- } \\
3 \text {; }\end{array}$ & 102 \\
\hline & & R: 5'- ATTTCCCATCCCAGTTTTTGT-3' & \\
\hline \multirow[t]{2}{*}{ CAPN3 } & NM_001009212.1 & F: 5'- GCCGCAATTTTCCCATTATT-3' & 125 \\
\hline & & R: 5'- GTAAAACAGGGAGGTCTCG-3' & \\
\hline \multirow[t]{2}{*}{ RPL7 } & XM_004011739.4 & $\begin{array}{l}\text { F: 5'- AAGCGACTGAGAAAGAAGTT- } \\
3 ;\end{array}$ & 191 \\
\hline & & R: 5'- CTGATGACAAACGCCAATTT-3' & \\
\hline \multirow[t]{2}{*}{ GAPDH } & NM_001034034.2 & $\begin{array}{l}\text { F: 5'- AGGTCGGAGTGAACGGATTC } \\
-3^{\prime}\end{array}$ & 219 \\
\hline & & $\begin{array}{l}\text { R: 5'- GGAAGATGGTGATGGCCTTT } \\
-3^{\prime}\end{array}$ & \\
\hline \multicolumn{4}{|c|}{ - Abbreviations: } \\
\hline \multicolumn{4}{|c|}{ - PCR, polymerase chain reaction; bp, base pair } \\
\hline
\end{tabular}


Table 2

Growth performance traits of Barki lambs under individually feeding and management system.

\begin{tabular}{|lllll|}
\hline Growth parameters & Slow growing & Intermediate growing & Fast growing & Overall means \\
\hline Birth Wight $(\mathrm{kg})$ & $3.83 \pm 0.2^{\mathrm{a}}$ & $2.82 \pm 0.2^{\mathrm{b}}$ & $4.10 \pm 0.2^{\mathrm{a}}$ & 3.92 \\
\hline Initial body Weight $(\mathrm{kg})$ & $15.8 \pm 1.2^{\mathrm{c}}$ & $22.5 \pm 1.2^{\mathrm{b}}$ & $27.7 \pm 1.2^{\mathrm{a}}$ & 23.27 \\
\hline Final body Weight $(\mathrm{kg})$ & $30.8 \pm 1.8^{\mathrm{c}}$ & $40.7 \pm 1.8^{\mathrm{b}}$ & $49.9 \pm 1.8^{\mathrm{a}}$ & 40.85 \\
\hline Average daily gain $(\mathrm{g})$ & $92.3 \pm 7.4^{\mathrm{b}}$ & $112.0 \pm 7.4^{\mathrm{ab}}$ & $173.6 \pm 7.4^{\mathrm{a}}$ & 118 \\
\hline Total body gain $(\mathrm{kg})$ & $15.0 \pm 1.2^{\mathrm{b}}$ & $18.2 \pm 1.2^{\mathrm{ab}}$ & $22.3 \pm 1.2^{\mathrm{a}}$ & 19.2 \\
\hline
\end{tabular}

Table 3

Carcass traits of Barki lambs under individually feeding and management system.

\begin{tabular}{|lllll|}
\hline Item & Slow growing & Intermediate growing & Fast growing & Overall means \\
\hline Hot Carcass weight $(\mathrm{kg})$ & $15.10 \pm 1.0^{\mathrm{c}}$ & $19.07 \pm 1.0^{\mathrm{b}}$ & $24.57 \pm 1.0^{\mathrm{a}}$ & 19.46 \\
\hline Dressing Percentage (\%) & $46.90 \pm 0.3$ & $47.48 \pm 0.3$ & $48.83 \pm 0.3$ & 47.70 \\
\hline Non-carcass fat $(\%)$ & $1.18 \pm 0.8$ & $1.21 \pm 0.8$ & $1.46 \pm 0.8$ & 1.22 \\
\hline Liver $(\mathrm{kg})$ & $0.54 \pm 0.2^{\mathrm{ab}}$ & $0.50 \pm 0.2^{\mathrm{b}}$ & $0.62 \pm 0.2^{\mathrm{a}}$ & 0.55 \\
\hline Tail Fat $(\%)$ & $1.48 \pm 0.8$ & 1.790 .34 & 1.650 .34 & 1.74 \\
\hline Total body fat $(\mathrm{kg})$ & $2.23 \pm 0.6$ & $2.61 \pm 0.1$ & $2.67 \pm 0.4$ & 2.57 \\
\hline
\end{tabular}

Table 4: Thyroid hormones, total protein, total lipids glucose and calcium profile of Barki lambs under individually feeding and management system.

\begin{tabular}{|lllll|}
\hline Item & Slow growing & Intermediate growing & Fast growing & Overall means \\
\hline $\mathrm{T} 3(\mathrm{ng} / \mathrm{ml})$ & $1.0 \pm 0.2$ & $0.63 \pm 0.2$ & $1.10 \pm 0.2$ & 0.90 \\
\hline $\mathrm{T} 4(\mathrm{ug} / \mathrm{dl})$ & $10.47 \pm 2.1$ & $12.37 \pm 2.1$ & $8.10 \pm 2.1$ & 8.49 \\
\hline Total protein $(\mathrm{g} / \mathrm{dl})$ & $6.07 \pm 0.8$ & $5.97 \pm 0.2$ & $6.53 \pm 0.2$ & 6.22 \\
\hline Total Lipids $(\mathrm{mg} / \mathrm{dl})$ & $392 \pm 11.5$ & $358 \pm 48.8$ & $378 \pm 16.4$ & 390 \\
\hline Glucose $(\mathrm{mg} / \mathrm{dl})$ & $74.17 \pm 0.8$ & $75.73 \pm 0.6$ & $74.87 \pm 2.3$ & 72.29 \\
\hline Calcium $(\mathrm{mg} / \mathrm{dl})$ & $10.87 \pm 2.2$ & $10.0 \pm 1.3$ & $10.13 \pm 1.3$ & 11.42 \\
\hline
\end{tabular}

\section{Figures}




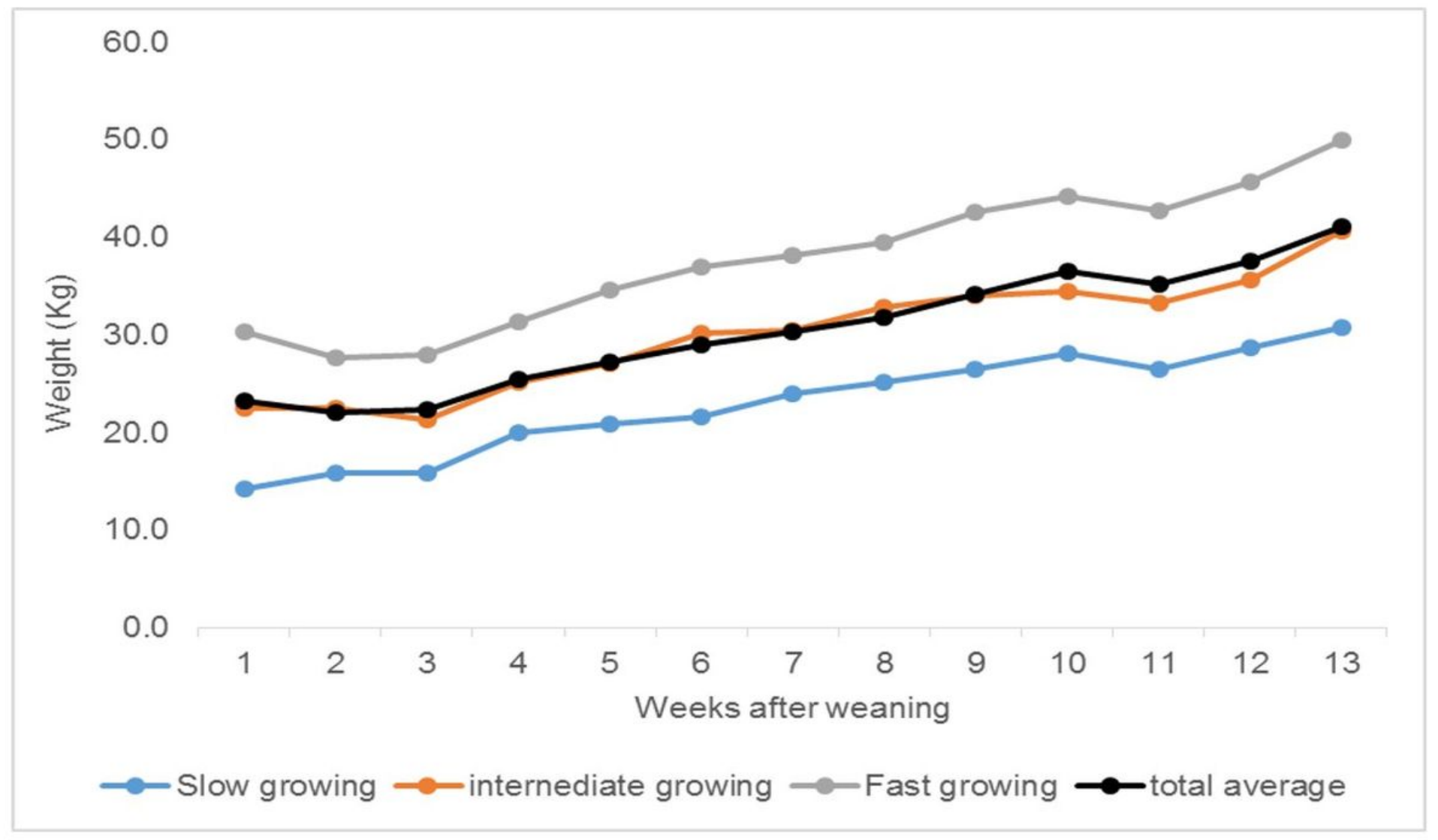

\section{Figure 1}

Growth rate of Barki lamb varied in growth performance under individually feeding and management system.

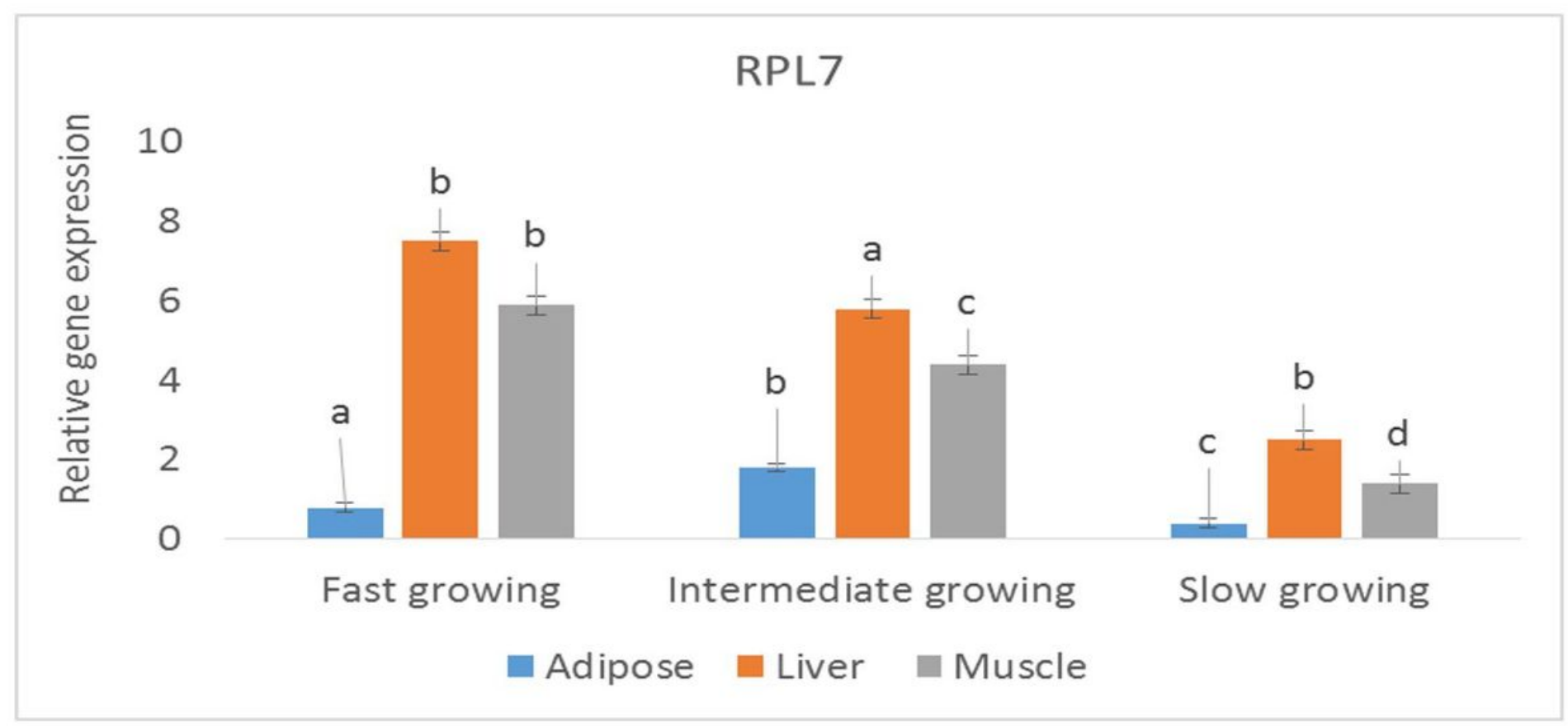

Figure 2 
Expression profile of protein biosynthesis gene (RPL7) in different body tissues of Barki lambs varied in growth performance under individually feeding and management system.

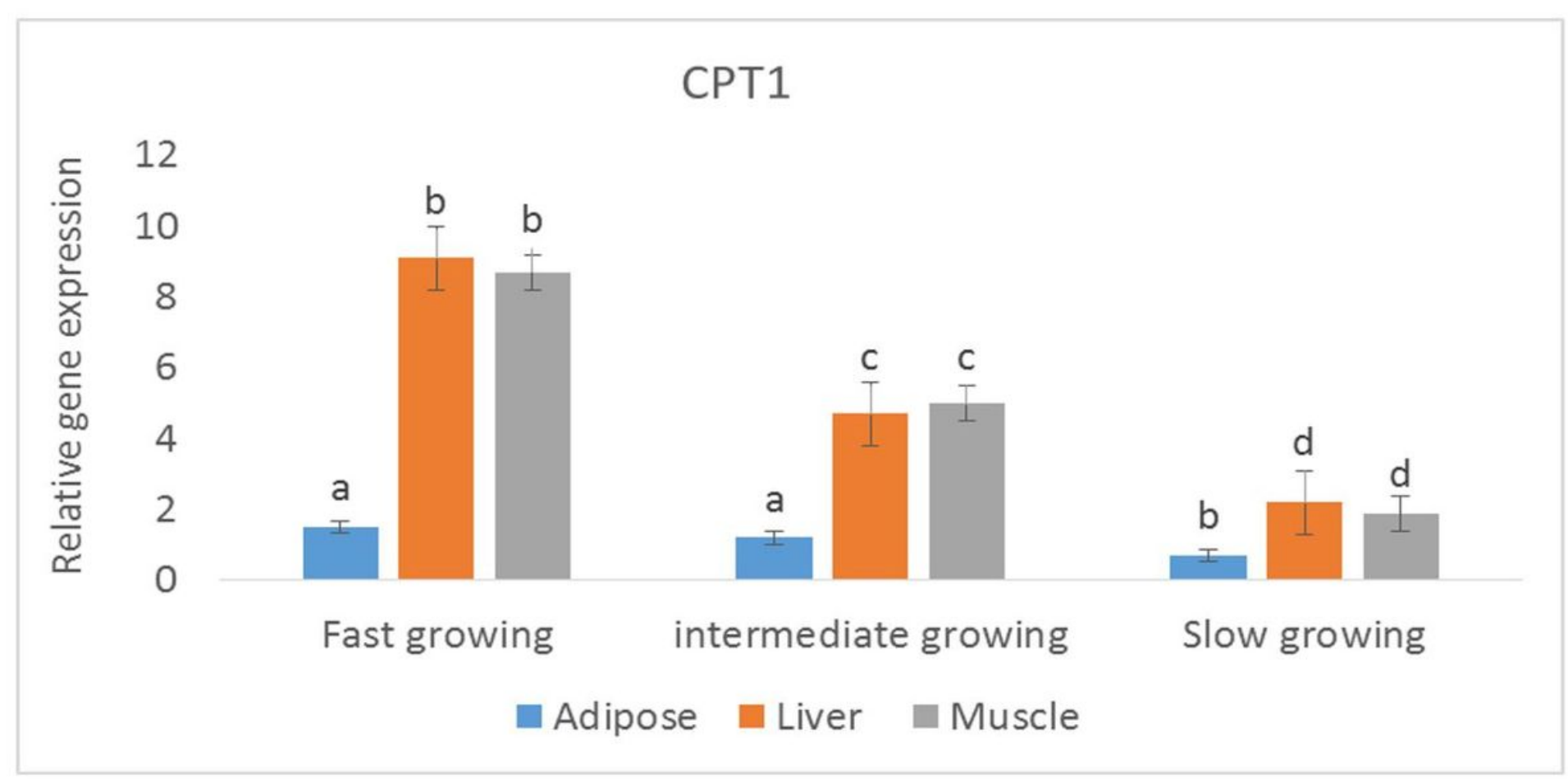

\section{Figure 3}

Expression profile of lipolysis gene (CPT1) in different body tissues of Barki lambs varied in growth performance under individually feeding and management system.

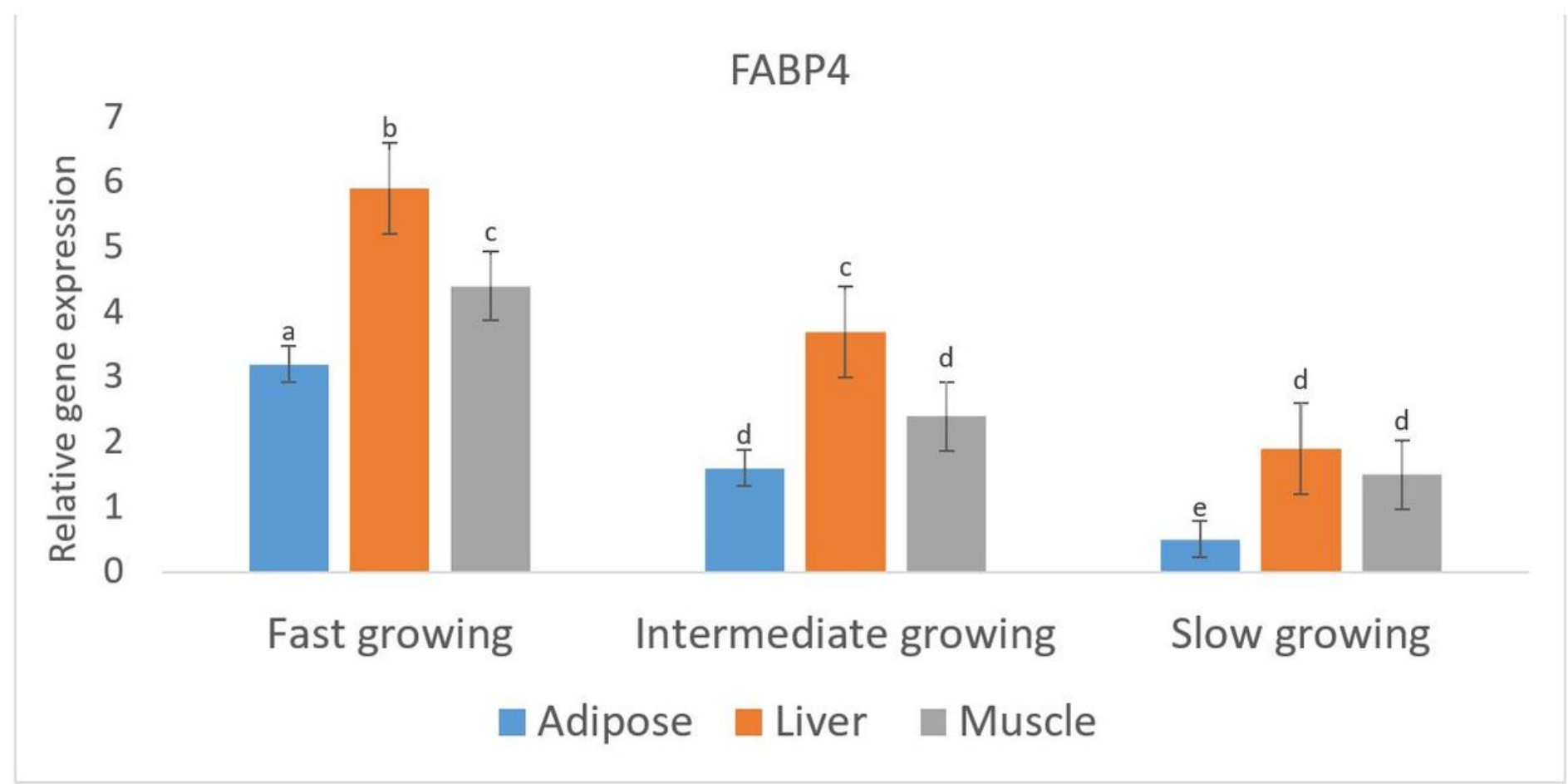


Expression profile of lipogenesis gene (FABP4) in different body tissues of Barki lambs varied in growth performance under individually feeding and management system.

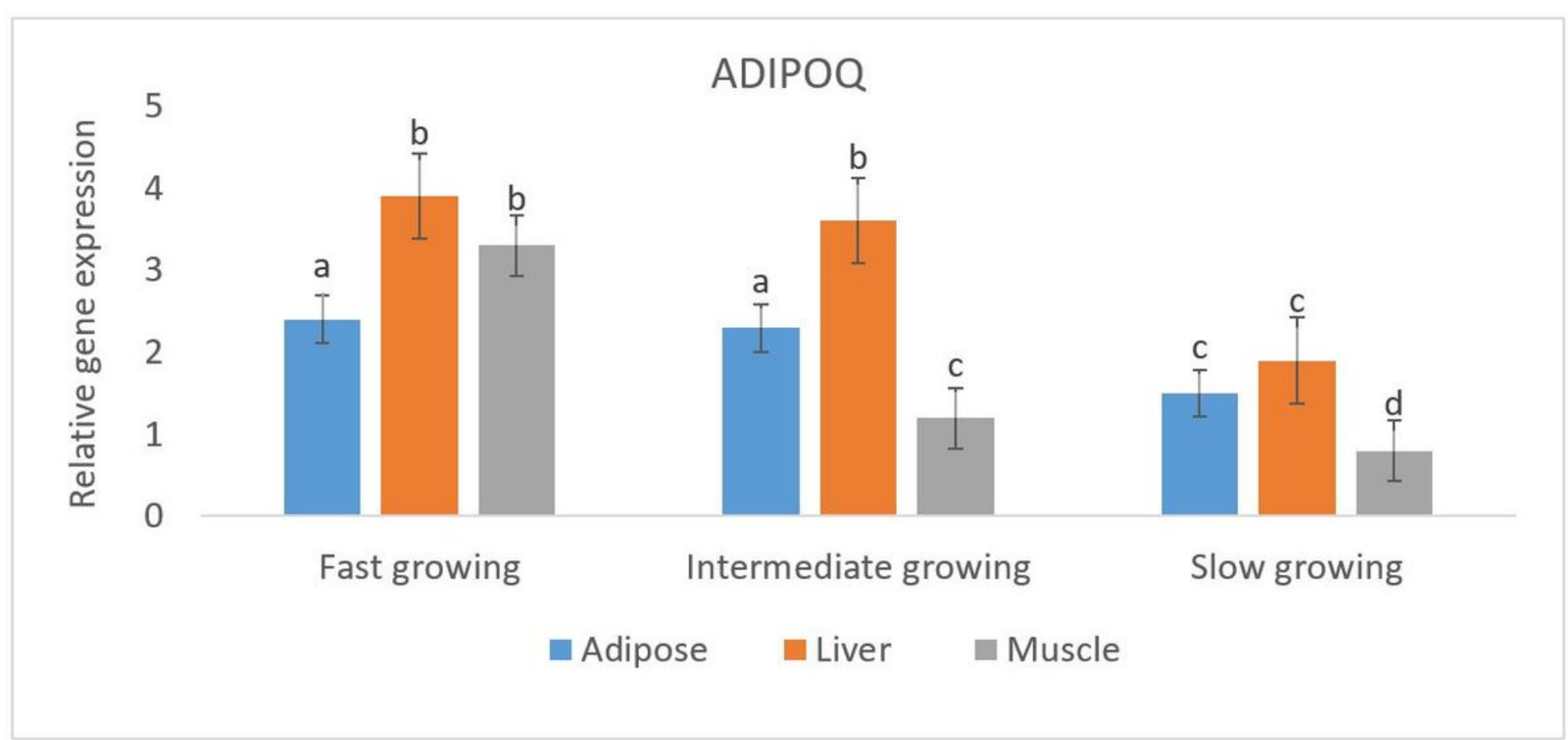

\section{Figure 5}

Expression profile of lipogenesis gene (ADIPOQ) in different body tissues of Barki lambs varied in growth performance under individually feeding and management system.

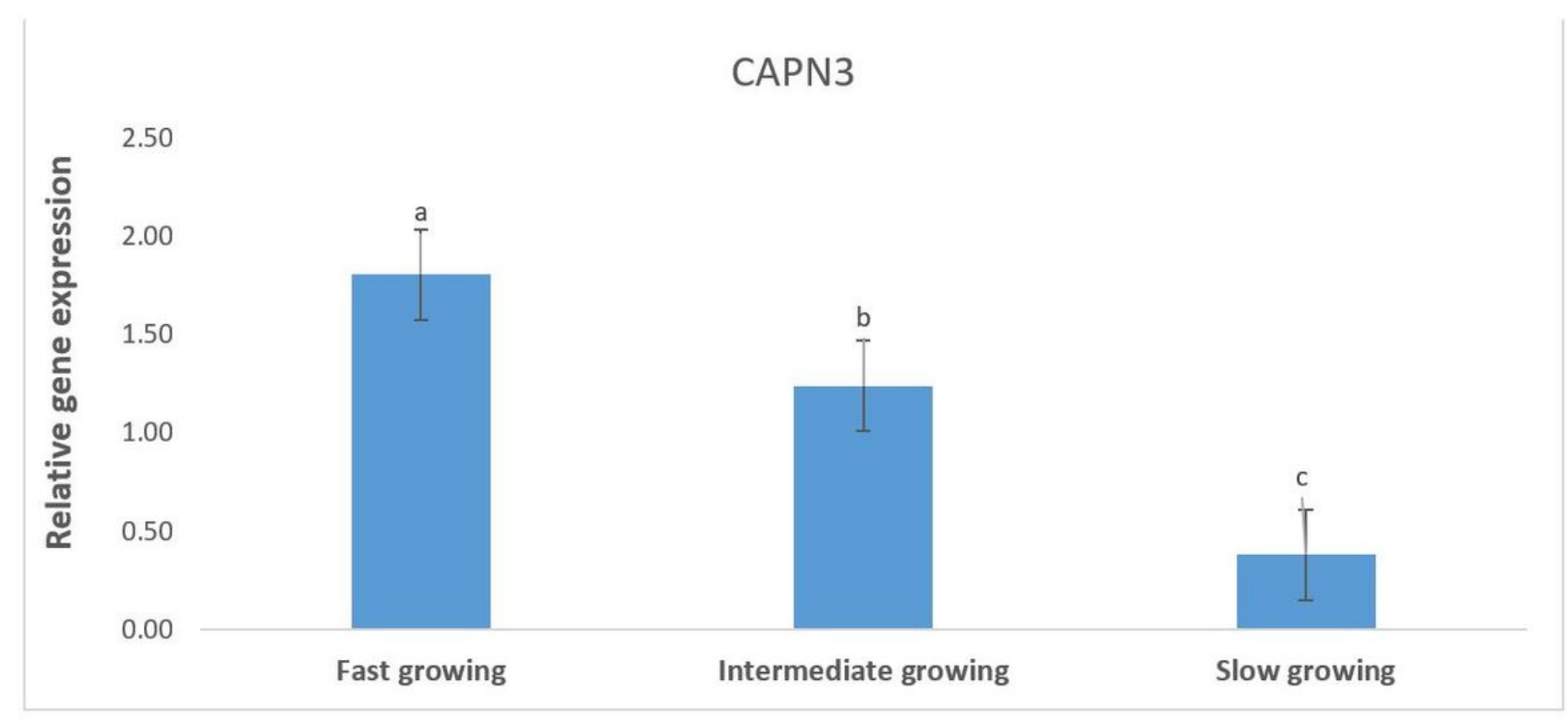

Figure 6 
Expression profile CAPN3 in muscle of Barki lambs) in muscle of Barki lambs varied in growth performance under individually feeding and management system. 